\title{
Auxin-induced Fruit Set in Capsicum annuum L. Requires Downstream Gibberellin Biosynthesis
}

\author{
Aparna Tiwari $\cdot$ Remko Offringa $\cdot$ Ep Heuvelink
}

Received: 23 September 2011/ Accepted: 24 February 2012/Published online: 27 March 2012

(C) The Author(s) 2012. This article is published with open access at Springerlink.com

\begin{abstract}
A hierarchical scheme for the central role of the plant hormones auxin and gibberellins in fruit set and development has been established for the model plants Arabidopsis and tomato. In the fruit crop Capsicum апnиит, the importance of auxin as an early signal in fruit set has also been recognized; however, the effect of gibberellins and their interaction with auxin has not yet been studied. The aim of this study was to determine the role of gibberellin and the hierarchy between auxin and gibberellin. We applied gibberellin alone or in combination with auxin or with the gibberellin biosynthesis inhibitor paclobutrazol on stigmas of emasculated flowers. Gibberellin application enhanced fruit set, whereas application of paclobutrazol reduced fruit set. The effect of paclobutrazol treatment could be counteracted by coapplication of gibberellin but not by auxin. These results indicate that in C. annuиm, like in Arabidopsis and tomato, auxin is the major inducer of fruit set that acts in part by inducing gibberellin biosynthesis. Interestingly, gibberellin does not significantly contribute to the final fruit size but seems to play an important role in preventing flower and fruit abscission, a major determinant of production loss in C. апnиит. At the same time, gibberellin together with
\end{abstract}

\footnotetext{
A. Tiwari · E. Heuvelink

Horticultural Supply Chains, Plant Sciences Group,

Wageningen University, P.O. Box 630, 6700 AP Wageningen,

The Netherlands

R. Offringa

Molecular and Developmental Genetics, Institute of Biology, Leiden University, Sylvius Laboratory, Sylviusweg 72,

2333 BE Leiden, The Netherlands

E. Heuvelink $(\bowtie)$

Droevendaalsesteeg 1, 6708 PB Wageningen, The Netherlands

e-mail: ep.heuvelink@wur.nl
}

auxin seems to balance cell division and cell expansion during fruit growth.

Keywords Hormones · Fruit set · Cell division · Cell expansion

\section{Introduction}

Fruit set and fruit development are part of a genetically controlled developmental program existing in most flowering plants (Gillaspy and others 1993). Usually the trigger of fruit set depends on the successful completion of pollination and fertilization, indicating the importance of pollination and seed-derived signals in fruit set and subsequent development (Sedgley 1989). Fruit development is important for plant reproduction because it provides a suitable environment for seed maturation and seed dispersal. Though seeds are important for plant reproduction, in most economically important fruit crops, for example, citrus, grape, melon, and pineapple, they are considered a nuisance because they decrease productivity and need to be removed during processing or before consumption (Gillaspy and others 1993). Fruit set without fertilization or parthenocarpy provides a solution to these problems (Gillaspy and others 1993). An important additional advantage of parthenocarpic plants is that they show fruit set and fruit development under environmental conditions that are unfavorable for successful pollination and fertilization (Gorguet and others 2008). For several fruit crops, parthenocarpy has been obtained by breeding methods that have relied on mutagenesis (for example, tomato) or alteration of the ploidy level (for example, banana and watermelon) (Spena and Rotino 2001). However, for many other crops genetic parthenocarpy is not available yet. In some species such as tomato and eggplant, 
external application of plant growth regulators has been proven to be effective for seedless fruit production in the absence of fertilization (Gillaspy and others 1993).

Auxin and gibberellins are two classes of plant hormones that are most frequently used to obtain parthenocarpic fruits (Dorcey and others 2009; Gillaspy and others 1993; Heuvelink and Körner 2001; Ozga and Reinecke 2003; Serrani and others 2008). External application of auxin (Alabadi and others 1996; Koshioka and others 1994; Ramin 2003; Serrani and others 2007a) and ectopic expression of genes encoding enzymes of auxin biosynthesis (Pandolfini and others 2002) induce fruit set in tomato. Similar to auxin, external application of gibberellin induces fruit set in several species (Dorcey and others 2009; Fos and others 2001; George and others 1984; Serrani and others 2007b). The application of both hormones on emasculated flowers at the optimal concentration can promote fruit development to the extent observed in seeded fruits, for example, tomato and pea (Ozga and Reinecke 2003; Serrani and others 2008; van Huizen and others 1996).

Several studies indicate that the application of auxin and gibberellin induces different changes in morphology, histology, and sugar metabolism during fruit development. For example, in tomato auxin-induced fruits are bigger than $\mathrm{GA}_{3}$-induced fruits, whereas in Arabidopsis the reverse is true (Serrani and others 2007a; Vivian-Smith and Koltunow 1999). Auxin stimulates cell division in tomato and cell expansion in Arabidopsis, whereas gibberellins stimulate cell expansion in tomato and cell division in Arabidopsis (Bunger-Kibler and Bangerth 1983; Serrani and others 2007a; Vivian-Smith and Koltunow 1999). A hierarchical scheme for the role of auxin and gibberellin in fruit set has been established for the model plants Arabidopsis and tomato, where auxin signals are mediated in part through the downstream gibberellin pathway (Dorcey and others 2009; Serrani and others 2008). The importance of indole-3-acetic acid (IAA) in parthenocarpic fruit set has been recognized in the vegetable crop sweet pepper (Capsicum annиum) (Heuvelink and Körner 2001). However, the effect of gibberellins on parthenocarpy induction and the interaction between auxin and gibberellin has not yet been studied in C. апnиит. To improve our understanding of the hormonal control of fruit set and development in $C$. аппиит, we studied the hierarchy between auxin and $\mathrm{GA}_{3}$ in fruit set and determined their effect on cell division and cell expansion.

\section{Material and Methods}

Plant Materials and Growth Conditions

Seeds of sweetpepper (Capsicum annuиm L.) cultivar 'Bruinsma Wonder' were obtained from Plant Research
International in Wageningen (PRI: 2004001) and of cultivar 'Riesen v.Californien' from The Centre for Genetic Resources, Wageningen, The Netherlands. Previous experiments have shown that both cultivars have a medium potential for parthenocarpic fruit set (unpublished data). Four weeks after sowing, seedlings were transplanted on rockwool cubes with a regular supply of nutrient solution. Four weeks after transplantation, plants were transferred on rockwool slabs at a density of 2.5 plants $\mathrm{m}^{-2}$ in a compartment of a multispan Venlo-type glasshouse in Wageningen, The Netherlands (latitude $52^{\circ} \mathrm{N}$ ). Nutrient solution was prepared according to Voogt and Bloemhard (1993) and was supplied by trickle irrigation. Supplemental lighting by high-pressure sodium lamps (Philips, SON-T, $600 \mathrm{~W}$ ) for $16 \mathrm{~h}$ (from 06.00 to 22.00 ) provided a minimum photon flux density of $125 \mu \mathrm{mol} \mathrm{m} \mathrm{m}^{-2} \mathrm{~s}^{-1}$ at the crop level. The terminal flower was removed from all plants at anthesis to support vegetative growth. The twin-branch system was applied, resulting in two stems per plant, with all side shoots restricted to a single leaf and flower.

\section{Hormone Applications}

Flowers were emasculated (removal of petals and anthers) 2 days before expected date of anthesis to avoid selfpollination. Using a spatula, the stigma of an emasculated flower was covered with lanolin paste at anthesis (day 0), mixed with water (1:1), without (control) or with hormone [dissolved in water or methanol (PCB) and mixed with heated lanolin $\left(100^{\circ} \mathrm{C}\right)$, stirred to a homogeneous paste, and cooled to room temperature]. Seeded fruits were obtained by natural pollination of nonemasculated flowers. Treatments [natural pollination: Poll; emasculation: Em; indole-3-acetic acid: IAA $\left(2 \times 10^{-5} \mathrm{M}\right)$; naphthalene acetic acid: NAA $\left(2 \times 10^{-5} \mathrm{M}\right)$; gibberellin: $\mathrm{GA}_{3}(1 \times$ $\left.10^{-5} \mathrm{M}\right)$, and paclobutrazol: PCB $\left.\left(1 \times 10^{-5} \mathrm{M}\right)\right]$ either alone or in combinations were applied to two flowers at each node (one flower on main branch and one flower on side branch) on both branches.

For cultivar Bruinsma Wonder, six plants per treatment were used, and flowers up to 10-15 nodes were treated in two experiments. For the first experiment, the numbers of treated flowers were $n=110$ for Poll, $n=80$ for Em, $n=74$ for Em + IAA, $n=84$ for Em $+\mathrm{GA}_{3}, n=70$ for $\mathrm{Em}+\left(\mathrm{IAA}+\mathrm{GA}_{3}\right)$. For the second experiment, the numbers of treated flowers were $n=30$ for Em, $n=11$ for $\mathrm{Em}+\mathrm{IAA}, n=12$ for $\mathrm{Em}+\mathrm{GA}_{3}, n=43$ for $\mathrm{Em}+\mathrm{PCB}, n=52$ for $\mathrm{Em}+\mathrm{PCB}+\mathrm{IAA}$, and $n=48$ for $\mathrm{Em}+\mathrm{PCB}+\mathrm{GA}_{3}$. The temperature set point was $20 / 20{ }^{\circ} \mathrm{C}$, although the realized temperature was $22.4 /$ $20.7{ }^{\circ} \mathrm{C}$ day/night $(\mathrm{D} / \mathrm{N})$. The treatments started in March and the experiment ended in June. 
For cultivar Riesen v.Californien, six plants were used for each treatment in two experiments. For the first experiment, flowers were treated until six fruits per plant were obtained. The remaining flowers were removed. Fruits were set at first, second, or third and sometimes up to the fourth node position. Treatments were Poll, Em, Em + IAA, Em + NAA, $\mathrm{Em}+\mathrm{GA}_{3}, \quad \mathrm{Em}+\left(\mathrm{IAA}+\mathrm{GA}_{3}\right)$, and $\mathrm{Em}+(\mathrm{NAA}+$ $\mathrm{GA}_{3}$ ). After harvesting of these fruits, new flowers on the same plants were used to test the effect of the gibberellin biosynthesis inhibitor PCB. Lanolin paste containing PCB was applied on the stigma of emasculated flowers, either alone or in combinations of hormones: $\mathrm{Em}+\mathrm{PCB}(n=$ $15), \mathrm{Em}+\mathrm{PCB}+\mathrm{NAA}(n=13)$, and $\mathrm{Em}+\mathrm{PCB}+\mathrm{GA}_{3}$ $(n=15) . \mathrm{GA}_{3}$ was applied on flowers that were earlier (1-2 days) treated with $\mathrm{Em}+\mathrm{PCB}+\mathrm{NAA}(n=11)$. Fruits were harvested 4-5 weeks after treatment and fruit set was calculated (factor of fruits of total treated flowers). The temperature set point was $20 / 20{ }^{\circ} \mathrm{C}$, although the realized temperature was $22.3 / 21.2{ }^{\circ} \mathrm{C} \mathrm{D} / \mathrm{N}$. The treatments started in September and experiments ended in December.

Fruits were harvested when they were completely red and their length, diameter, and fresh weight were measured. Fruits with a fresh weight below $50 \%$ of the average weight of fruits obtained after natural pollination were considered as knots and the remaining fruits were considered as normal fruits. In all experiments, knots were included only for the determination of fruit set and excluded for all other measurements, that is, fruit weight and percentage fruit with carpelloid structures. The number of days required from anthesis until fruit maturity was calculated in all fruits of cv. Riesen v.Californien.

\section{Measurement of Cell Division and Cell Expansion}

Plants of $C$. annuum cultivar 'Bruinsma Wonder' were grown between December and July, as described above, in an air-conditioned greenhouse at 20.4/20.2 ${ }^{\circ} \mathrm{C}$ day/night temperature. Five plants were used per treatment and only one flower per node was treated with Poll, Em, Em + IAA, $\mathrm{Em}+\mathrm{GA}_{3}, \mathrm{Em}+\left(\mathrm{IAA}+\mathrm{GA}_{3}\right)$, or $\mathrm{Em}+\left(\mathrm{IAA}+\mathrm{GA}_{3}\right)$. For each treatment, three to five fruits were harvested at 60 days after anthesis (DAA). Length, diameter, and fresh weight were measured and the number of cell layers and cell diameter in the carpel were evaluated.

To evaluate cell division and cell expansion, horizontal cross sections of the carpel were mounted, stained with "safranin O" (stock solution: $2.5 \mathrm{~g}$ safranin O Certistain ${ }^{\circledR}$ in $100 \mathrm{ml}$ of $96 \%$ ethanol; working solution: 1:100 dilution in water), and observed under a Zeiss Axioplan 2 fluorescence/DIC microscope. Photographs were taken with a Zeiss AxioCam MRc 5 digital color camera. Cell diameter was measured using Image tool version 3.0. For each treatment, 20-30 cells were observed from four to five sections per fruit. The number of cell layers was counted in mesocarp layers as a measure of cell division. The cell diameter was measured in the mesocarp area, five to six layers below the exocarp as a measure of cell expansion.

\section{Statistical Analysis}

The effect of auxin (IAA, NAA), $\mathrm{GA}_{3}$, and PCB on fruit set and fruit size was tested in a one-way analysis of variance (ANOVA). $\mathrm{GA}_{3}$ treatment and emasculation were excluded from this ANOVA due to the large variation as a result of their small sample size only in cv. Riesen v.Californien. Mean separation was done by Student's $t$ test (least significant difference, LSD) based on the ANOVA mentioned above. The change in the number of cell layers and cell diameter was also tested in a one-way ANOVA. Data processing and statistical tests were carried out using SPSS v15.0.

\section{Results}

Capsicum annuum Fruit Set is Induced by Auxin and Requires Downstream Gibberellin Biosynthesis

To study the hierarchical order of the action of auxin and gibberellin in fruit set in C. annuum, auxin (IAA) and the gibberellin $\left(\mathrm{GA}_{3}\right)$ were applied separately or in combination on stigmas of emasculated flowers of cultivar 'Bruinsma Wonder'. Under our growth conditions, following emasculation, already $34 \%$ of the flowers in this cultivar developed into fruits, of which one third remained too small to be considered normal fruits (below $50 \%$ of the weight of seeded fruits) and were called knots. Hormone application enhanced fruit set, and this effect was stronger for $\mathrm{GA}_{3}(60 \%)$ and IAA $+\mathrm{GA}_{3}(63 \%)$ application than for IAA application (46\%) (Fig. 1a). The percentage of knots was reduced with the application of IAA but not with the application of $\mathrm{GA}_{3}$ and IAA $+\mathrm{GA}_{3}$ compared to only emasculation (Fig. 1a). The fruits of Bruinsma Wonder often contained internal outgrowths that partially or fully occupied the fruit cavity; they were named carpelloid structures as these outgrowths most likely resulted from homeotic conversion of aberrant ovules (Fig. 2b-e). A possible inverse relationship between seed development and carpelloid structure was observed as the number of carpelloid structure-containing fruits increased from $40 \%$ in seeded fruits to $75 \%$ in seedless fruits. This suggests that carpelloid structures can acquire available assimilates and grow prominently in the absence of fertilization; however, seeds could compete better for assimilates thus explaining this inverse relationship. 

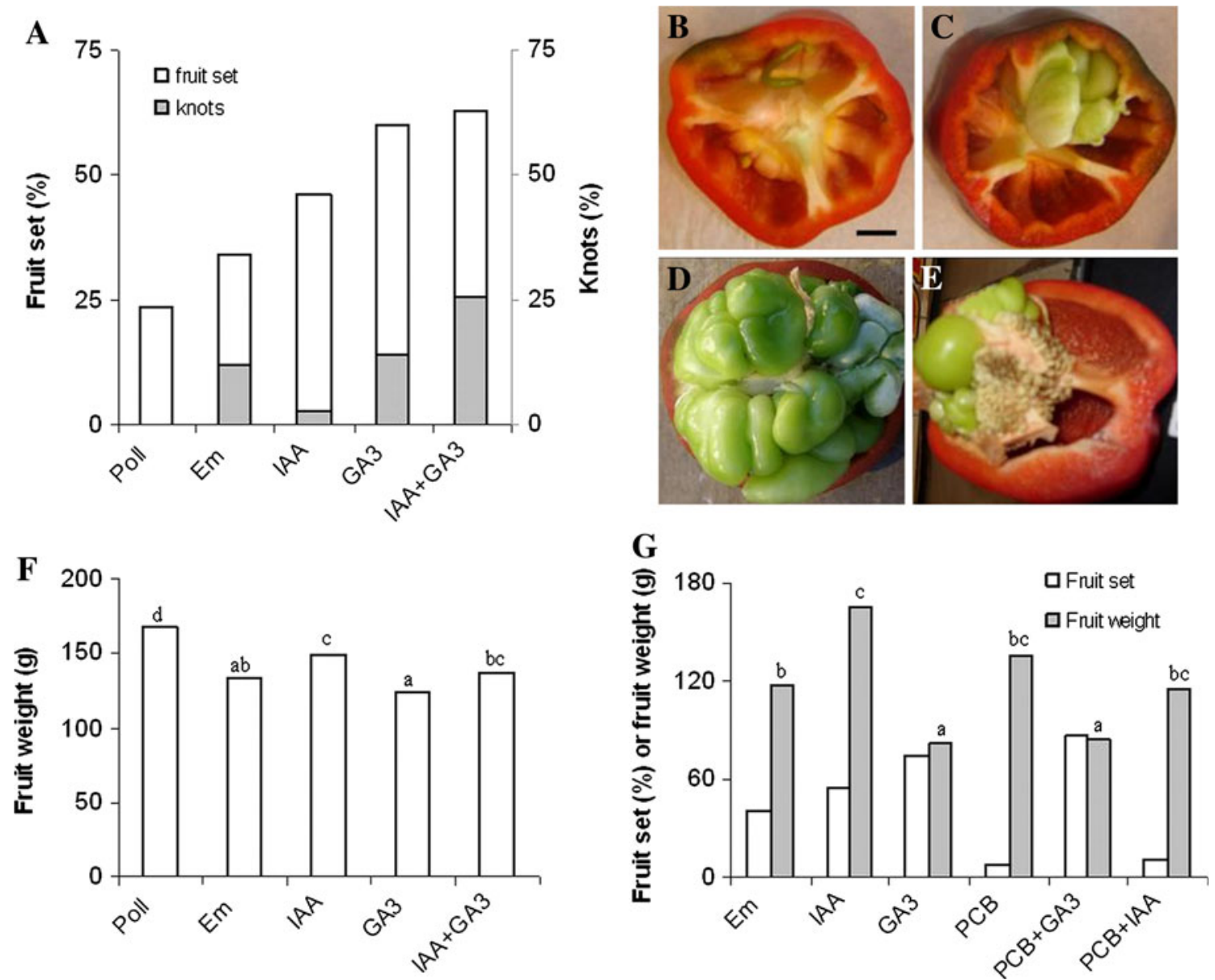

Fig. 1 The effect of auxin and $\mathrm{GA}_{3}$ on seedless fruit set and development and carpelloid structures in Capsicum annuum cultivar 'Bruinsma Wonder'. a Percentage of fruit set including percentage of knots. b-e Structure and position of carpelloid development in seedless fruit with minor (b), medium (c), and strong (d) growth, and in seeded fruits at the base of placenta (e). Scale bar $=1 \mathrm{~cm}$ for (b-e). f Average weight ( $\mathrm{g}$ ) of fruits obtained from untreated (Poll, $n=26$ ) or emasculated flowers (Em, $n=27$ ), or from emasculated flowers that were treated with IAA $(n=33), \mathrm{GA}_{3}(n=43)$,

The average weight of parthenocarpic fruits (excluding knots) obtained by emasculation or application of auxin and $\mathrm{GA}_{3}$ on emasculated flowers $(149 \pm 5.8 \mathrm{~g}$ for IAA, $123 \pm 3.9 \mathrm{~g}$ for $\mathrm{GA}_{3}, 137 \pm 3.8 \mathrm{~g}$ for IAA $\left.+\mathrm{GA}_{3}\right)$ was smaller than that of seeded fruits $(167 \pm 5.2 \mathrm{~g}, P<0.001$; Fig. 1f). Fruits obtained after $\mathrm{GA}_{3}$ application were significantly smaller than auxin-induced fruits $(P<0.001)$. Simultaneous application of auxin and gibberellin did not increase the fruit weight more than IAA did $(P=0.056)$ (Fig. 1f). These results indicate that IAA enhances both fruit set and fruit weight and reduces the number of knots, whereas $\mathrm{GA}_{3}$ enhances fruit set but results in smaller fruit size at maturity.

To test whether auxin-induced fruit set is dependent on de novo gibberellin biosynthesis, like it is in Arabidopsis

IAA $+\mathrm{GA}_{3}(n=40)$. $\mathrm{g}$ Percentage of fruit set and fruit weight in fruits obtained after emasculation (Em, $n=12$ ) or after emasculation followed by IAA $(n=4), \mathrm{GA}_{3}(n=5)$, paclobutrazol (PCB) $(n=3)$, $\mathrm{PCB}+\mathrm{GA}_{3}(n=19)$, or PCB + IAA $(n=5)$ application. Different letters above the bars represent different classes that are significantly different according to Student's $t$ test $(P=0.05)$. Fruits with a fresh weight below $50 \%$ of the average weight of naturally pollinated fruits were considered as knots. Knots are included for the measurement of fruit set and excluded for other measurements

and tomato, we applied auxin and gibberellin in combination with the gibberellin biosynthesis inhibitor paclobutrazol (PCB). PCB application alone reduced fruit set from 30 to $7 \%$. Fruit set was improved to $88 \%$ when PCB was applied in combination with $\mathrm{GA}_{3}$ but not when applied in combination with IAA (12\%) (Fig. 1g). These results indicate that auxin-induced fruit set is partially mediated by the gibberellin pathway. The fruit weight after IAA and $\mathrm{GA}_{3}$ application was in accordance with the previous observation (Fig. 1f) where $\mathrm{GA}_{3}$-induced fruits were smaller than IAA-induced fruits. The fruit weight obtained after PCB treatment was comparable to that obtained after emasculation or emasculation followed by IAA treatment. These observations led to a model where auxin acts upstream of gibberellin in fruit set, most likely by inducing 

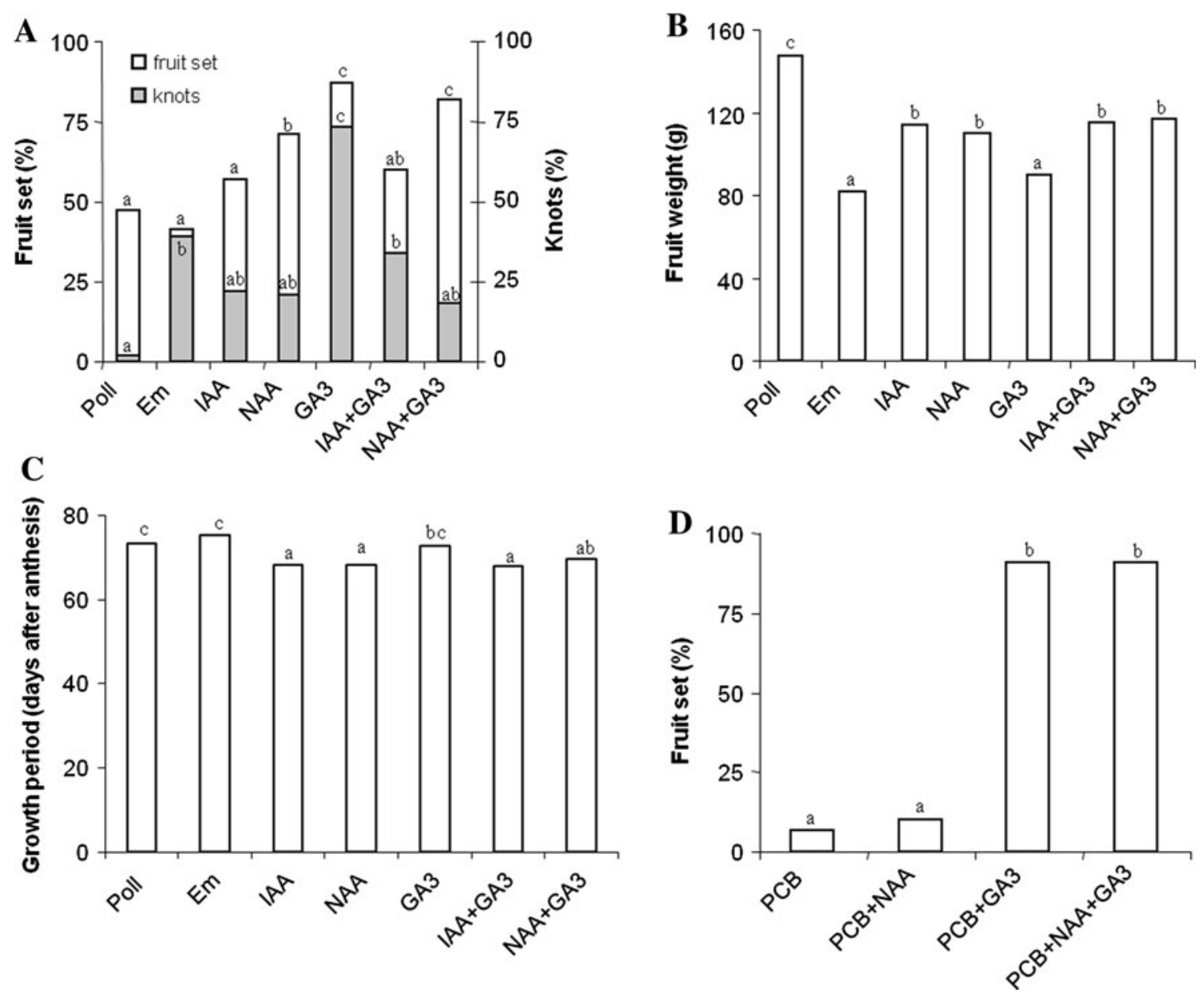

Fig. 2 Evaluation of fruit set and fruit development in Capsicum annuum cultivar 'Riesen v.Californien' under constant fruit load conditions. a Percentage of fruit set, including percentage of knots. Fruits with fresh weights below $50 \%$ of the average weight of naturally pollinated fruits were considered as knots. Knots are included for the measurement of fruit set and excluded for other measurements. b Average fruit weight $(\mathrm{g})$ obtained after pollination and fertilization (Poll, $n=17$ ), emasculation (Em, $n=11$ ), or emasculation followed by IAA $(n=21)$, NAA $(n=23), \mathrm{GA}_{3}$

gibberellin biosynthesis, and is important for full fruit development (reduced number of knots), whereas $\mathrm{GA}_{3}$ is required for fruit set by reducing flower abscission. As such, it is difficult to conclude that $\mathrm{GA}_{3}$ reduces fruit size, as the smaller fruit size might be caused by the increased number of fruits per plant.

\section{$\mathrm{GA}_{3}$-enhanced Fruit Set Results in Smaller Fruits Due to Reduced Growth Rate}

We subsequently analyzed whether our observations in cv. Bruinsma Wonder could be reproduced in genotype Riesen v.Californien. In addition, to check whether reduced fruit weight after $\mathrm{GA}_{3}$ application was caused by the higher number of fruits per plant or by their reduced capacity to attract assimilates, only six fruits were allowed to set per $(n=8)$, IAA $+\mathrm{GA}_{3}(n=21)$, or NAA $+\mathrm{GA}_{3}(n=27)$ application. Six plants with six fruits per plant were used for each treatment. c Growth period (from anthesis until ripening) for all the fruits obtained from different treatments (same as b). d Percentage of fruit set after application of PCB on stigmas of emasculated flowers, either alone $(n=1)$ or in combination with NAA $(n=1), \mathrm{GA}_{3}(n=10)$, or $\mathrm{NAA}+\mathrm{GA}_{3}(n=10)$. Different letters above the bars represent different classes that are significantly different according to the LSD test $(P=0.05)$

plant by removing the subsequent flowers. Like with Bruinsma Wonder (Fig. 1), emasculation in Riesen v.Californien resulted in fruit set (41\%) and hormone application enhanced the percentage of fruit set, where the effect of $\mathrm{GA}_{3}$ was greater $(87 \%)$ than that of IAA $(57 \%) . \mathrm{GA}_{3}$ application increased the percentage of knots (73\%), whereas this was reduced after NAA $(21 \%)$ and IAA (22 \%) application compared to emasculation only (Fig. 2a). More than $50 \%$ of seeded and seedless fruits contained carpelloid structures. The placental origin of carpelloid structures and the variability in their size was the same as observed for Bruinsma Wonder (Fig. 1b-e). The average weight of parthenocarpic fruits was less than that of seeded fruits $(P<0.001)$ (Fig. 2b). NAA- and IAAinduced fruits were comparable in weight (Fig. 2b), but fruit set after NAA application was higher than that after 
IAA (Fig. 2a). Application of $\mathrm{GA}_{3}$ resulted in fruit size smaller than IAA- or NAA-induced fruits $(P=0.036)$ and comparable to fruit size obtained from untreated emasculated flowers. Simultaneous application of IAA and $\mathrm{GA}_{3}$ resulted in fruits with a weight similar to that of IAAinduced fruits $(P=0.252)$ (Fig. $2 b)$. No difference in growth period (number of days required from anthesis till fruit maturity) was observed between $\mathrm{GA}_{3}$-induced and auxin-induced fruits or between $\mathrm{GA}_{3}$-induced and pollination/fertilization-induced fruits (Fig. 2c). Because the fruit load per plant was kept constant $(n=6)$, the competition between the fruits would be less than in Bruinsma Wonder (Fig. 1), where all flowers up to $10-15$ nodes were treated. This suggests that smaller fruit size after $\mathrm{GA}_{3}$ application is the result of a reduced growth rate and not because of competition between fruits.

To test whether the hierarchy between auxin and gibberellin is also the same as observed in cv. Bruinsma Wonder, we applied auxin and gibberellin in combination with the gibberellin biosynthesis inhibitor PCB. PCB application alone reduced fruit set from 47 to $7 \%$. The fruit set was improved to $91 \%$ when PCB was applied in combination with $\mathrm{GA}_{3}$ but not when applied in combination with NAA (10 \%). Application of $\mathrm{GA}_{3}$ on NAA and PCB-treated flowers resulted in increased fruit set (91\%) (Fig. 2d). These results confirm our previous observation in Bruinsma Wonder that auxin initiates fruit set and is crucial for full fruit development, and they strongly suggest that auxin-induced gibberellin biosynthesis is required for fruit set.

\section{$\mathrm{GA}_{3}$ Stimulates Cell Division and Auxin Stimulates Cell Expansion During Fruit Growth}

To clarify the effect of $\mathrm{GA}_{3}$ and auxin on cell division and cell expansion, we compared the histology of seeded and seedless fruit of $\mathrm{cv}$. Bruinsma Wonder at 60 DAA. The carpel section showed a single layer of exocarp cells, multiple layers of mesocarp cells, and two layers of (giant and small) endocarp cells (Fig. 3a). The number of cell layers in the mesocarp was used as a measure of cell division (Fig 3a, broken arrow). The average number of cell layers in the mesocarp was $22( \pm 0.6)$ in fruits obtained after emasculation and $27( \pm 0.4)$ in fruits obtained after pollination. The number of cell layers in $\mathrm{GA}_{3}$-induced fruits $(26 \pm 0.4)$ was not different than that from fruits obtained after pollination $(P=0.313)$, whereas IAA-induced fruits $(23 \pm 0.8 ; P=0.012)$ developed significantly fewer cell layers (Fig. 3b). Because a gradient in cell size was observed from the exterior to the interior of the mesocarp, we used the same four to six layers (starting from layer 5 from the exterior) to measure the diameter of individual cells (Fig. 3a, box; Fig. 3c, arrow). The mean cell diameter was the same in fruits obtained after pollination or IAA application $(P=0.585)$, although it was significantly smaller in fruits obtained after $\mathrm{GA}_{3}$ application $(P=0.001) \quad$ (Fig. 3b). The simultaneous application of IAA and $\mathrm{GA}_{3}$ resulted in a cell diameter intermediate that obtained with auxin and gibberellin application. These data indicate that during fruit growth auxin stimulates cell expansion and $\mathrm{GA}_{3}$ enhances cell division. This, together with the observation that auxininduced fruits in general are bigger than $\mathrm{GA}_{3}$-induced fruits, suggests that cell expansion is an important determinant of the final fruit size in $C$. апnиum.

\section{Discussion}

To test the role of gibberellin fruit set and to investigate the hierarchy between auxin and gibberellin, we studied the effect of $\mathrm{GA}_{3}$ (the most commonly used gibberellin) and auxin (IAA, NAA) on fruit set and fruit growth in C. апnиит cv. 'Bruinsma Wonder' and 'Riesen v.Californien'. External application of $\mathrm{GA}_{3}$ and auxin on the stigma of emasculated flowers enhanced parthenocarpic fruit set compared to only emasculation, indicating the importance of both hormones in fruit set. However, application of these two hormones could not reproduce the exact fruit size and shape observed following fertilization. Apparently, seeds also have other roles in stimulating fruit size besides being a source of gibberellin and auxin (Gillaspy and others 1993; Mapelli and others 1978; Sjut and Bangerth 1982). The majority of seedless fruits showed development of carpelloid structures, suggesting that the absence of fertilization stimulates development of carpelloid structures. This observation is in line with previous reports (Tiwari and others 2007, 2011) where carpelloid structures were prominent in seedless fruits, although fewer or no carpelloid structures were reported in seeded fruits.

\section{Auxin-induced Fruit Set Requires Downstream Gibberellin Biosynthesis to Reduce Abscission}

The IAA- or NAA-induced fruits were comparable in size, but NAA-induced fruit set was higher, which could be due to its longer-lasting effect (more stable synthetic hormone) compared to IAA (unstable natural hormone) (Paciorek and others 2005; Staswick 2009). In contrast to Arabidopsis (Vivian-Smith and Koltunow 1999), but similar to tomato (Serrani and others 2007a), we found that fruits obtained after $\mathrm{GA}_{3}$ application were smaller than fruits obtained after auxin application. This smaller size is a consequence of a reduced growth rate, as the time required from anthesis until mature ripe fruit did not differ between $\mathrm{GA}_{3^{-}}$and auxin-induced fruits (Fig. 2c). A likely reason for smaller fruit size after $\mathrm{GA}_{3}$ application compared to that after auxin 
A
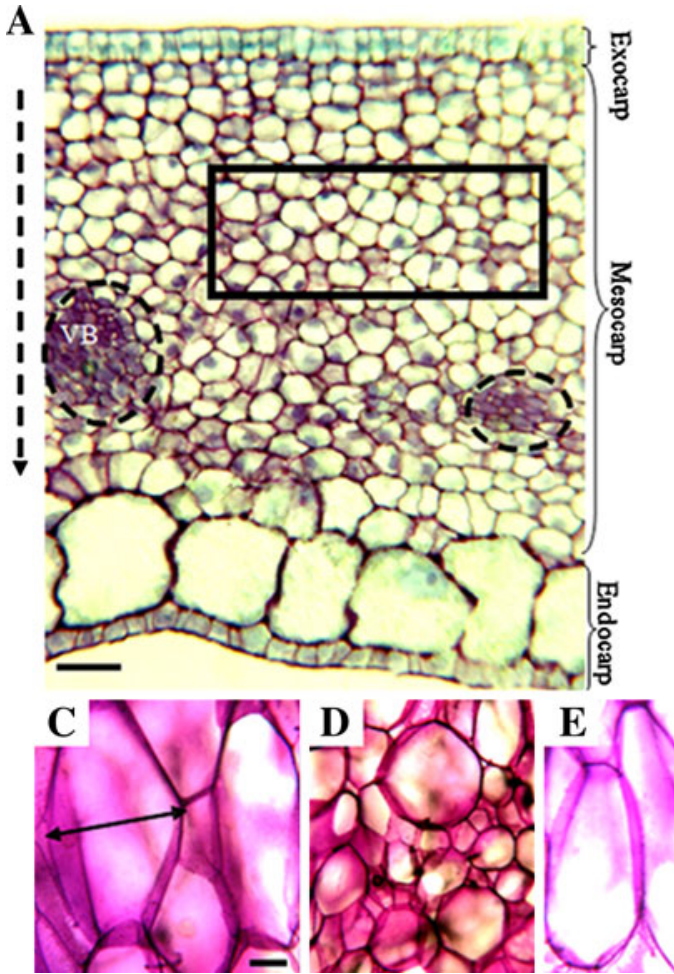

Fig. 3 Analysis of cell division and expansion in mesocarp layers from fruits of Capsicum аппиит cultivar 'Bruinsma Wonder' at 60 days after anthesis. a Representative image of a horizontal cross section of the carpel with the indication of an area (box) from which cell diameters were measured and differentiation of layers into exocarp (outer single layer), mesocarp (multilayered), and endocarp (two-layered). $V B$ vascular bundle. b Average number of cell layers and average cell diameter from fruit obtained after pollination (Poll), emasculation (Em), and emasculation followed by IAA, $\mathrm{GA}_{3}$, or

application is that gibberellin alone does not whereas auxin does trigger the first steps of fruit initiation, and that at the same time auxin stimulates gibberellin biosynthesis, as has been observed in tomato through the transcriptional activation of GA 20-oxidases(Marti and others 2007; Olimpieri and others 2007; Serrani and others 2007b).

Application of PCB reduced fruit set in cv. Bruinsma Wonder and Riesen v.Californien (Figs. 1g, 2d). PCB is an inhibitor of gibberellin biosynthesis that inhibits P450dependent dioxygenases (Serrani and others 2007b). Subsequent application of gibberellin could overcome the inhibitory effect of PCB and resulted in normal fruit set. These experiments also nicely demonstrated in C. апnиит that auxin acts upstream of gibberellin biosynthesis during fruit initiation. These results are consistent with the model of hormone action in fruit set reported in tomato and Arabidopsis where auxin signals are mediated through gibberellin pathways (Dorcey and others 2009; Frigerio and others 2006; Serrani and others 2008).

Gibberellin had no additional effect on fruit growth, as treatment with $\mathrm{GA}_{3}$ alone did not increase fruit size
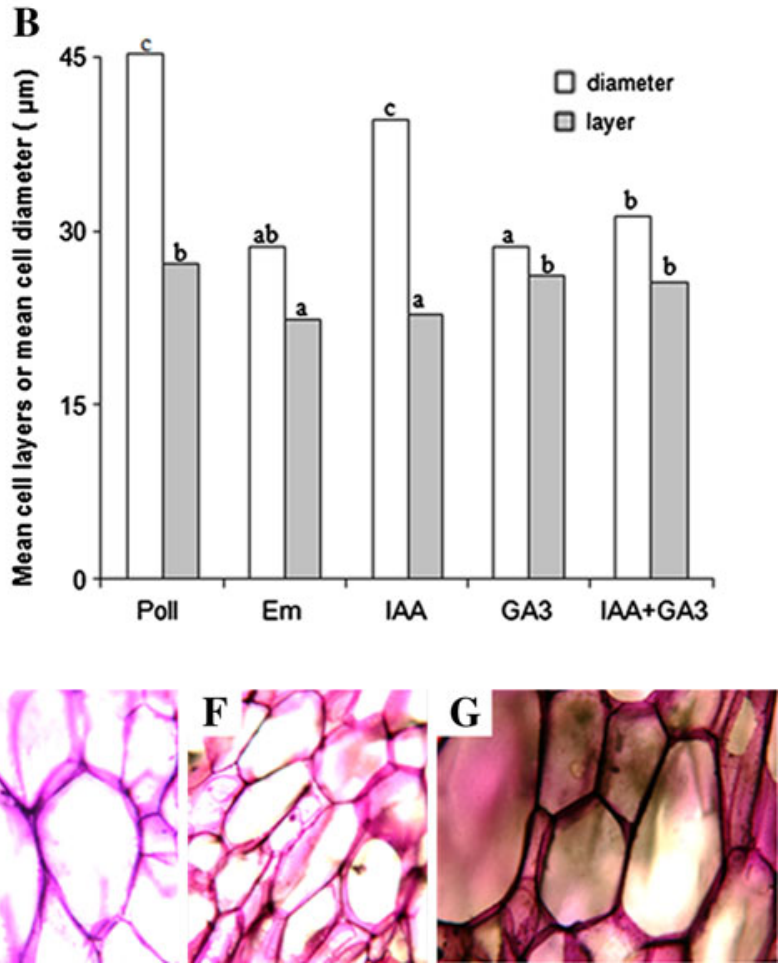

IAA $+\mathrm{GA}_{3}$ application $(n=3-5)$. Different letters above the bars represent different classes that are significantly different according to the LSD test $(P=0.05)$. $\mathbf{c}-\mathbf{g}$ Detail of a horizontal cross section of the mesocarp in mature fruits, showing parts of the region from which cell size was measured in the transverse direction (arrow). Fruits were obtained from pollinated (c) or emasculated flowers (d) or from emasculated flowers treated with IAA (e), $\mathrm{GA}_{3}$ (f), or IAA $+\mathrm{GA}_{3}$ (g). Scale bars $=50 \mu \mathrm{m}(\mathbf{a})$ or $20 \mu \mathrm{m}(\mathbf{c}-\mathbf{g})$

compared to emasculation only, and combined treatment with auxin and $\mathrm{GA}_{3}$ did not result in bigger fruits compared to auxin treatment alone (Figs. 1f, 2c). This result is in contrast to tomato and pea where simultaneous application of gibberellin and auxin resulted in larger fruit size than auxin-induced fruits and fruit more similar to that induced by pollination and fertilization (Serrani and others 2007a; van Huizen and others 1996). However, experimental conditions such as stage of development, emasculation, or elimination of seeds might influence the final result. A likely mechanism by which $\mathrm{GA}_{3}$ enhances fruit set in C. аппиит is by prevention of flower or fruit abscission, because in $C$. апnиит this process is easily induced by environmental and growth conditions (Pressman and others 1998). Gibberellins are well recognized as antagonists of abscisic acid in the control of fruit growth in pea and citrus (Eeuwens and Schwabe 1975; García-Martinez and Carbonell 1980; Mahouachi and others 2005).

By avoiding flower abscission, gibberellin-treated ovaries might stay longer on the plant and thus have a higher chance that the fruit development program is initiated. For 
many of such ovaries, however, the auxin levels are not sufficiently induced to trigger full fruit development and thus these ovaries result in knots. In tomato, these knots are also known as misshapen fruits, pseudo fruits, puffs, or nuts (Carmi and others 2003; Serrani and others 2007a). $\mathrm{GA}_{3}$-induced fruits in tomato show poorly developed locular tissue that lacks jelly inside the cavity. Although these fruits have not been called knots, their characteristics do not support calling them normal fruit (Serrani and others 2007a).

$\mathrm{GA}_{3}$ Stimulates Cell Division and Auxin Stimulates Cell Expansion During Fruit Growth

The diameter of the fruits is significantly smaller when $\mathrm{GA}_{3}$ is added along with IAA compared to that obtained with the addition of IAA alone. In contrast, there are significantly more mesocarp cell layers when $\mathrm{GA}_{3}$ is added with IAA compared to that obtained with the addition of IAA alone. This suggests that $\mathrm{GA}_{3}$ addition might be inhibiting the cell expansion induced by IAA. The coordinated action of auxin and gibberellin is required for normal fruit development in tomato (Bunger-Kibler and Bangerth 1983), blueberry (Cano-Medrano and Darnell 1997), citrus (Guardiola and others 1993), rape (Srinivasan and Morgan 1996), watermelon (Sedgley and others 1977), pea (Vercher and Carbonell 1991; Vercher and others 1987), and Arabidopsis (Vivian-Smith and Koltunow 1999). Our results show that this is also the case for C. апnиит, as $\mathrm{GA}_{3}$ is required for fruit set and stimulates mesocarp cell division and auxin stimulates mesocarp cell expansion, whereas application of both hormones or fertilization stimulates both cell division and cell expansion (Fig. 3b). These observations are similar to those for Arabidopsis (Vivian-Smith and Koltunow 1999) but in contrast to those for tomato where $\mathrm{GA}_{3}$ stimulates mesocarp cell expansion and auxin stimulates mesocarp cell division (Bunger-Kibler and Bangerth 1983; Serrani and others 2008). Although both hormones are required for normal fruit development, fruit weight obtained after simultaneous application of auxin and gibberellin was not similar to that of fruits obtained after fertilization (Figs. 1f, $2 \mathrm{~b}$ ), suggesting that not only these hormones but also other factors and/or other hormones might be involved in regulating the final fruit size.

\section{Conclusion}

Our results clearly demonstrate that external application of auxin (IAA, NAA) and $\mathrm{GA}_{3}$ on stigmas of emasculated flowers enhances parthenocarpic fruit set compared to fruits obtained after emasculation only. The hierarchy between auxin and gibberellin in fruit set in $C$. апnиum is the same as reported in Arabidopsis and tomato where $\mathrm{GA}_{3}$ biosynthesis acts downstream of auxin. In $C$. annuum, $\mathrm{GA}_{3}$ seems to have an essential role in promoting fruit set whereas auxin seems to be important for both fruit set and fruit development. Application of auxin or $\mathrm{GA}_{3}$ resulted in smaller fruit size than seeded fruits, which is a result of reduced cell division or cell expansion, respectively. Simultaneous application of auxin and gibberellin could also not reproduce the exact fruit size and shape of seeded fruits, suggesting that seeds have other roles in stimulating fruit size besides being a source of auxin and gibberellin.

Acknowledgments We thank Hans Dassen and Maarten Peters for their help with the laboratory measurements and greenhouse experiments. This research was funded by the Dutch Technology Foundation (STW), which is the applied science division of the Netherlands Organization of Scientific Research (project No. LPB 6822).

Open Access This article is distributed under the terms of the Creative Commons Attribution License which permits any use, distribution, and reproduction in any medium, provided the original author(s) and the source are credited.

\section{References}

Alabadi D, Aguero MS, PerezAmador MA, Carbonell J (1996) Arginase, arginine decarboxylase, ornithine decarboxylase and polyamines in tomato ovaries-changes in unpollinated ovaries and parthenocarpic fruits induced by auxin or gibberellin. Plant Physiol 112:1237-1244

Bunger-Kibler S, Bangerth F (1983) Relationship between cellnumber, cell-size and fruit size of seeded fruits of tomato (Lycopersiconesculentum Mill), and those induced parthenocarpically by the application of plant-growth regulators. Plant Growth Regul 1:143-154

Cano-Medrano R, Darnell RL (1997) Sucrose metabolism and fruit growth in parthenocarpic vs seeded blueberry (Vaccinium ashei) fruits. Physiol Plant 99:439-446

Carmi N, Salts Y, Dedicova B, Shabtai S, Barg R (2003) Induction of parthenocarpy in tomato via specific expression of the rolB gene in the ovary. Planta 217:726-735

Dorcey E, Urbez C, Blazquez MA, Carbonell J, Perez-Amador MA (2009) Fertilization-dependent auxin response in ovules triggers fruit development through the modulation of gibberellin metabolism in Arabidopsis. Plant J 58:318-332

Eeuwens CJ, Schwabe WW (1975) Seed and pod wall development in Pisum sativum L. in relation to extracted and applied hormones. J Exp Bot 26:1-14

Fos M, Proano K, Nuez F, Garcia-Martinez JL (2001) Role of gibberellins in parthenocarpic fruit development induced by the genetic system pat-3/pat-4 in tomato. Physiol Plant 111:545-550

Frigerio M, Alabadi D, Perez-Gomez J, Garcia-Carcel L, Phillips AL, Hedden P, Blazquez MA (2006) Transcriptional regulation of gibberellin metabolism genes by auxin signaling in Arabidopsis. Plant Physiol 142:553-563

García-Martinez JL, Carbonell J (1980) Fruit-set of unpollinated ovaries of Pisum sativum L. Influence of plant growth regulators. Planta 147:451-456

George W, Scott J, Spilttstoesser W (1984) Parthenocarpy in tomato. Hortic Rev 6:65-84 
Gillaspy G, Bendavid H, Gruissem W (1993) Fruits-a developmental perspective. Plant Cell 5:1439-1451

Gorguet B, Eggink PM, Ocana J, Tiwari A, Schipper D, Finkers R, Visser RGF, van Heusden AW (2008) Mapping and characterization of novel parthenocarpy QTLs in tomato. Theor Appl Genet 116:755-767

Guardiola JL, Barres MT, Albert C, Garcia-Luis A (1993) Effect of exogenous growth regulators on fruit development in Citrus unshiu. Ann Bot 71:169-176

Heuvelink E, Körner O (2001) Parthenocarpic fruit growth reduces yield fluctuation and blossom-end rot in sweet pepper. Ann Bot 88:69-74

Koshioka M, Nishijima T, Yamazaki H, Liu Y, Nonaka M, Mander LN (1994) Analysis of gibberellins in growing fruits of Lycopersiconesculentum after pollination or treatment with 4-chlorophenoxyacetic acid. J Hortic Sci 69:171-179

Mahouachi J, Gomez-Cadenas A, Primo-Millo E, Talon M (2005) Antagonistic changes between abscisic acid and gibberellins in citrus fruits subjected to a series of different water conditions. J Plant Growth Regul 24:179-187

Mapelli S, Frova C, Torti G, Soressi GP (1978) Relationship between set, development and activities of growth regulators in tomato fruits. Plant Cell Physiol 19:1281-1288

Marti C, Orzaez D, Ellul P, Moreno V, Carbonell J, Granell A (2007) Silencing of DELLA induces facultative parthenocarpy in tomato fruits. Plant J 52:865-876

Olimpieri I, Siligato F, Caccia R, Mariotti L, Ceccarelli N, Soressi GP, Mazzucato A (2007) Tomato fruit set driven by pollination or by the parthenocarpic fruit allele are mediated by transcriptionally regulated gibberellin biosynthesis. Planta 226:877-888

Ozga JA, Reinecke DM (2003) Hormonal interactions in fruit development. J Plant Growth Regul 22:73-81

Paciorek T, Zazimalova E, Ruthardt N, Petrasek J, Stierhof YD, Kleine-Vehn J, Morris DA, Emans N, Jurgens G, Geldner N, Friml J (2005) Auxin inhibits endocytosis and promotes its own efflux from cells. Nature 435:1251-1256

Pandolfini T, Rotino GL, Camerini S, Defez R, Spena A (2002) Optimization of transgene action at post-transcriptional level: high quality parthenocarpic fruits in industrial tomatoes. BMC Biotech 2:1

Pressman E, Moshkovitch H, Rosenfeld K, Shaked R, Gamliel B, Aloni B (1998) Influence of low night temperatures on sweet pepper flower quality and the effect of repeated pollinations, with viable pollen, on fruit setting. J Hortic Sci Biotech 73:131-136

Ramin AA (2003) Effects of auxin application on fruit formation in tomato growing under stress temperatures in the field. J Hortic Sci Biotech 78:706-710

Sedgley M (1989) Ovule and seed development in Eucalyptuswoodwardii maiden (symphyomyrtus). Bot Gaz 150:271-280

Sedgley M, Newbury HJ, Possingham JV (1977) Early fruit development in the watermelon: anatomical comparison of pollinated, auxin-induced parthenocarpic and un-pollinated fruits. Ann Bot 41:1345-1355

Serrani JC, Fos M, Atares A, Garcia-Martinez JL (2007a) Effect of gibberellin and auxin on parthenocarpic fruit growth induction in the cv. micro-tom of tomato. J Plant Growth Regul 26:211-221

Serrani JC, Sanjuán R, Ruiz-Rivero O, Fos M, Garcia-Martinez JL (2007b) Gibberellin regulation of fruit set and growth in tomato. Plant Physiol 145:922-934

Serrani JC, Ruiz-Rivero O, Fos M, Garcia-Martinez JL (2008) Auxininduced fruit-set in tomato is mediated in part by gibberellins. Plant J 56:922-934

Sjut V, Bangerth F (1982) Induced parthenocarpy: a way of changing the levels of endogenous hormones in tomato fruits (Lycopersicon esculentum Mill.): 1. extractable hormones. Plant Growth Regul 1:243-251

Spena A, Rotino GL (2001) Parthenocarpy: state of the art. In: Bhojwani SS, Soh WY (eds) Current trends in the embryology of angiosperms. Kluwer Academic Publishers, Amsterdam, pp $435-450$

Srinivasan A, Morgan DG (1996) Growth and development of the pod wall in spring rape (Brassica napus) as related to the presence of seeds and exogenous phytohormones. J Agric Sci 127:487-500

Staswick PE (2009) The tryptophan conjugates of jasmonic and indole-3-acetic acids are endogenous auxin inhibitors. Plant Physiol 150:1310-1321

Tiwari A, Dassen H, Heuvelink E (2007) Selection of sweet pepper (Capsicum annuиm L.) genotypes for parthenocarpic fruit growth. Acta Hort 761:135-140

Tiwari A, Vivian-Smith A, Voorrips RE, Habets MEJ, Xue LB, Offringa R, Heuvelink E (2011) Parthenocarpic potential in Capsicum annuum $\mathrm{L}$. is enhanced by carpelloid structures and controlled by a single recessive gene. BMC Plant Biol 11:143

van Huizen R, Ozga JA, Reinecke DM (1996) Influence of auxin and gibberellin on in vivo protein synthesis during early pea fruit growth. Plant Physiol 112:53-59

Vercher Y, Carbonell J (1991) Changes in the structure of ovary tissues and in the ultra structure of mesocarp cells during ovary senescence or fruit development induced by plant growth substances in Pisum sativum. Physiol Plant 81:518-526

Vercher Y, Molowny A, Carbonell J (1987) Gibberellic acid effects of the ultra-structure of endocarp cells of un-pollinated ovaries of Pisum sativum. Physiol Plant 71:302-308

Vivian-Smith A, Koltunow AM (1999) Genetic analysis of growthregulator-induced parthenocarpy in Arabidopsis. Plant Physiol 121:437-451

Voogt W, Bloemhard C (1993) Voedingsoplossingen voor de teelt van paprika in steenwol en bij hergebruik van drainwater (5th revised ed). In: Voedingsoplossingen in de glastuinbouw 13. Naaldwijk, The Netherlands: Research Station for Floriculture and Glass-house Vegetables 